\title{
PERAN KELUARGA TERHADAP LANSIA di PUSKESMAS REJOSARI
}

\author{
Liva Maita \\ Program Studi DIII Kebidanan STIKes Hang Tuah Pekanbaru \\ STIKes Hangtuah Pekanbaru, Indonesia \\ email : livamaita@gmail.com
}

\begin{abstract}
In Indonesia the attention to the elderly population increases mainly due to the number that tends to increase rapidly. In 2010, the number of elderly residents living in urban areas was 12,380,321 people (9.58\%), and those living in rural areas of 15.612.232 people (9.97\%). There is a considerable difference between the elderly in the city and in the village. This difference can be due to the migration patterns of young people to the city and their old age prefer to their village, and villagers have a greater life expectancy because they do not breathe polluted air, do not often face the things that make them more stressful, tentramnya rather than the days of stress, and also because the food consumed is not contaminated with pesticides, thus making them not susceptible to disease. General Purpose Knowledge of family role to health of elderly at Rejosari Health Center Pekanbaru year 2013. Type of research was descriptive. Sample in this study as many as 94 elderly who taken mengguankan purposive sampling technique, the data were analyzed univariat. The result of the research showed the role of family in the health examination of the elderly with good category (88,30\%), the role of family in the fulfillment of good nutrition of elderly with good category $(98,94 \%)$, family role in meeting the needs of rest and sleep of elderly with good category $(91,94 \%)$ and the role of family with good category (95\%). It is expected that the PHC to improve the Elderly Health Program in PHC through health examination and gymnastics elderly every week.
\end{abstract}

Keywords: Rejosari Health Center, Family Role Against the Elderly.

Abstrak: Di Indonesia perhatian terhadap penduduk lansia meningkat terutama karena jumlahnya yang cenderung meningkat pesat. Pada tahun 2010, jumlah penduduk lansia yang tinggal di perkotaan sebesar 12.380.321 jiwa (9,58\%), dan yang tinggal di pedesaan sebesar 15.612.232 jiwa (9,97\%). Terdapat perbedaan yang cukup besar antara lansia di kota dan di desa. Perbedaan ini bisa terjadi karena pola migrasi penduduk usia muda ke kota dan saat tuanya lebih memilih ke desanya, dan penduduk desa memiiki usia harapan hidup lebih besar karena tidak menghirup udara yang sudah berpolusi, tidak sering menghadapi hal-hal yang membuat mereka stres, lebih banyak tentramnya ketimbang harihari stres, dan juga karena makanan yang di konsumsi tidak terkontaminasi dengan pestida, sehingga membuat mereka tidak mudah terserang penyakit. Tujuan Umum Diketahuinya peran keluarga terhadap kesehatan lansia di Puskesmas Rejosari Pekanbaru tahun 2013. Jenis penelitian yang digunakan deskriptif. Sample dalam penelitian ini sebanyak 94 lansia yang diambil mengguankan teknik purposif sampling, data dianalisis secara univariat. Hasil penelitian didapatkan peran keluarga dalam pemeriksaan kesehatan lansia dengan kategori baik $(88,30 \%)$, peran keluarga dalam pemenuhan nutrisi lansia dengan kategori baik $(98,94 \%)$, peran keluarga dalam pemenuhan kebutuhan istirahat dan tidur lansia dengan kategori baik $(91,94 \%)$ dan peran keluarga dengan kategori baik (95\%). Diharapkan kepda pihak Puskesmas untuk dapat meningkatkan Program Kesehatan 
Lansia di Puskesmas melalui kegiatan pemeriksaan kesehatan dan senam lansia setiap minggunya.

Kata Kunci $\quad$ : Puskesmas Rejosari, Peran Keluarga Terhadap Lansia.

\section{PENDAHULUAN}

Indonesia sebagai salah satu negara berkembang juga mengalami peningkatan populasi penduduk lansia dari $4,48 \%(5,3$ juta jiwa) pada tahun 1971 menjadi 9,77\% (23,9 juta jiwa) pada tahun 2010. Bahkan pada tahun 2020 diprediksi akan terjadi ledakan jumlah penduduk lansia sebesar $11,34 \%$ atau sekitar 28,8 juta jiwa (Makmur 2006 dalam Fatmah, 2010).

Pada tahun 2010, jumlah penduduk lansia yang tinggal di perkotaan sebesar 12.380 .321 jiwa $(9,58 \%)$, dan yang tinggal di pedesaan sebesar 15.612.232 jiwa (9,97\%). Untuk Propinsi Riau, khususnya Pekanbaru, berdasarkan Dinas Kesehatan Kota Pekanbaru tahun 2012 jumalah lansia 3215 jiwa. Puskesmas Rejosari adalah Puskesmas yang memiliki jumlah lansia terbanyak pada tahun 2012 sebanyak 1532 jiwa.

$\begin{array}{cccc}\text { Keluarga } & \text { merupakan } & \text { support } \\ \text { system bagi } & \text { lansia } & \text { dengan }\end{array}$ mempertahankan kesehatannya. Peran keluarga dalam pelayanan lansia antara lain menjaga kesehatan lansia, memenuhi nutrisi lansia, pola istirahat lansia, dan merawat lansia. Mempertahankan dan meningkatkan status mental, mengantisipasi perubahan sosial ekonomi, serta membarikan motivasi dan memfasilitasi perubahan sosial ekonomi lansia (Maryam, 2008). Saat ini keluarga yang mengasuh lansia kurang memperhatikan kesehatan lansia sehingga sangat banyak lansia terkena penyakit hipertensi, diabetes, stroke dan lain-lain.

Berdasarkan uraian diatas terlihat peran keluarga terhadap kesehatan lansia sungguh sangat penting, maka degan itu peneliti tertarik untuk mengetahui Gambaran Peran Keluarga Terhadap Kesehatan Lansia.

\section{METODE}

Jenis penelitian ini adalah deskriptif. Populasi penelitian ini adalah keluarga yang mempunyai lansia di Puskesmas Rejosari Pekanbaru pada berjumlah 1532 orang. Sampel adalah sebagian keluarga yang mempunyai lansia di Puskesmas Rejosari dengan kriteria sampel lansia dengan usia diatas 60 tahun, Lansia yang tinggal dengan keluarga, Keluarga yang bersedia jadi responden, yang berjumlah 94 orang. Cara mengambil data melalui penyebaran kuisioner kepada responden yang dijadikan objek penelitian. Analisa data univariat

\section{HASIL \& PEMBAHASAN \\ a. Hasil}

Berdasarkan tabel 1 didapatkan hasil yaitu : responden yang berusia 2030 tahun sebanyak 47 orang (50\%), umur $>30$ tahun sebesar 47 orang $(50 \%)$. responden pendidikan rendah yaitu sebanyak 48 (51,06\%). responden dengan pemeriksaan kesehatan pada kategori baik sebanyak 83 orang $(88,30 \%)$ dan cukup 11 orang $(11,30 \%)$. peran keluarga terhadap pemenuhan kebutuhan nutrisi lansia adalah pada kategori baik sebanyak 93 orang $(98,94 \%)$. peran keluarga terhadap pemenuhan kebutuhan istirahat dan tidur adalah pada kategori baik sebanyak 86 orang $(91,94 \%)$. peran keluarga adalah pada kategori baik sebanyak 89 orang $(95 \%)$. 
Tabel 1. Hasil Analisa Univariat Variabel Penelitian

\begin{tabular}{|c|c|c|}
\hline Variabel & Frekuensi & Presentase \\
\hline \multicolumn{3}{|l|}{ Umur } \\
\hline 20 - 30 tahun & 47 & 50 \\
\hline$>30$ tahun & 47 & 50 \\
\hline Jumlah & 94 & 100 \\
\hline \multicolumn{3}{|l|}{ Pendidikan } \\
\hline SD & 8 & 8,51 \\
\hline SMP & 40 & 42,55 \\
\hline SMA & 37 & 39,36 \\
\hline PT & 9 & 9,57 \\
\hline Jumlah & 94 & 100 \\
\hline \multicolumn{3}{|l|}{ Pemeriksaan } \\
\hline \multicolumn{3}{|l|}{ Kesehatan } \\
\hline Baik & 83 & 88,30 \\
\hline Cukup & 11 & 11,70 \\
\hline Jumlah & 94 & 100 \\
\hline \multicolumn{3}{|l|}{ Pemenuhan } \\
\hline \multicolumn{3}{|l|}{ Nutrisi } \\
\hline Baik & 93 & 98,94 \\
\hline Cukup & 1 & 1,06 \\
\hline Jumlah & 94 & 100 \\
\hline \multicolumn{3}{|l|}{ Istirahat dan } \\
\hline Baik & 86 & 91,49 \\
\hline Cukup & 8 & 8,51 \\
\hline Jumlah & 94 & 100 \\
\hline Peran & & \\
\hline \multicolumn{3}{|l|}{ Keluarga } \\
\hline Baik & 89 & 95 \\
\hline Cukup & 5 & 5 \\
\hline Jumlah & 94 & 100 \\
\hline
\end{tabular}

\section{b. Pembahasan}

Berdasarkan hasil penelitian diketahui bahwa sebagian besar peran keluarga menyatakan bahwa keluarganya mendukung lansia untuk berkunjung di puskesmas 89 orang (95\%). Hasil penelitian ini sesuai dengan teori yang dikemukakan Natoatmodjo (2003), bahwa untuk mewujudkan sikap agar menjadi suatu perbuatan nyata diperlukan faktor pendukung atau suatu kondisi yang memungkinkan, antara lain fasilitas dan support (faktor pendukung) dari pihak lain salah satunya adalah keluarga.
Mayoritas peran keluarga terhadap pemenuhan pemeriksaan kesehatan pada kategori baik sebanyk 83 orang $(88,30 \%)$. Hal senada juga dinyatakan oleh mariam (2008) yang menyatakan bahwa dalam melakukan perawatan terhadap lansia, setiap anggota keluarga memiliki peranan yang sangat penting salah satunya adalah memeriksakan kesehatan minimal 6 bulan sekali untuk mendeteksi penyakit pada lansia.

Mayoritas peran keluarga terhadap pemenuhan kebutuhan nutrisi lansia adalah pada kategori baik sebanyak 93 orang $(98.94 \%)$. Hasil penelitian di atas sesui dengan pendapat mariam (2008) yang mengemukakan bahwa dalam melakukan perawatan terhadap lansia, setiap anggota keluarga memiliki peranan yang sangat penting salah satunya adalah membantu melakukan persiapan makanan bagi lansia. Persiapan makanan disisni haruslah dengan memperhatikan gizi yang cukup seperti pendapat yang di kemukakan Pandji (2012).

Mayoritas peran keluarga terhadap pemenuhan kebutuhan istirahat dan tidur adalah pada kategori baik sebanyak 86 orang (91.94 \%). Hasil penelitian ini sesui dengan pendapat Selamihardja (2007) yang menyatakan bahwa untuk mendapatkan suasana tidur yang menyenangkan bagi lanjut usia, keluarga berperan menyediakan tempat tidur yang nyaman, mengatur lingkungan yang cukup ventilasi bebas dari baubauan, melakukan latihan ringan untuk mempelancar sirkulasi darah atau dengan minim-minuman hangat sebelum tidur.

\section{SIMPULAN}

Berdasarkan hasil penelitian didapatkan distribusi frekwensi peran kelurga tentang pemeriksaan kesehatan yaitu 83 orang $(88.30 \%)$ dengan kategori baik, peran keluarga tentang pemenuhan kebutuhan nutrisi yaitu 93 orang (98.94 $\%)$ dengan kategori baik, peran keluarga 
tentang pemenuhan kebutuhan istirahat dan tidur lansia yaitu 86 orang $(91.94 \%)$.

\section{DAFTAR PUSTAKA}

Fatimah. (2010). Gizi Usia Lanjut. Jakarta : Erlangga.

Maryam, Siti, dkk. (2008). Mengenal Usia Lanjut dan Perawatannya. Jakarta : Salemba Medika.
Natoatmodjo. (2003). Pengantar ilmu prilaku kesehatan. Jakarta : PT. Rineka Cipta.

Pandji, Dewi. (2012). Menembus Dunia Lansia. Jakarta: Kelompok Gramedia.

Salamihardja, (2007). Tidur Yang Nyaman, www.kompas.go.id, 24 Mei 2009. Jakarta: Salemba Mendika. 